\title{
Innovative undertakings in the Polish industry*
}

\author{
Jan Zwolak ${ }^{1}$
}

\begin{abstract}
The purpose of this research is to determine if there is any correlation between the sale of new or significantly improved products and the physical capital and human capital in the Polish industry between 2011 and 2013. In the quantitative analysis a Cobb-Douglas regression model has been used and together with its parameters it has obtained results which indicate a higher degree of flexibility of the sale of new and significantly improved goods relative to real capital expenditure streams (0.868) than human capital investment flows (0.190). The model of innovation growth rate (Cobb-Douglas theory) indicates that the flexibility of sold production of new and significantly improved goods can be equal to unity. The research has found regression dependence of new and substantively improved products sold on the physical and human capital expenditure. Thus, there is an imbalance of these capitals in the impact on the volatility of sold production of new and significantly improved goods in the industry. The above-specified production relative to the combined effect of real and human capital investment flows was growing more than proportionally (1.058) in the industry in the years 2011-2013. The current potential for innovation with an unchanged production method allows us to obtain increasing economies of scale of production sold of new and significantly improved goods in the Polish industry. The conducted research shows that the impact of human capital (0.190) amounts only to one-fifth of the potential opportunities available in the Polish industry.
\end{abstract}

Key words: innovation, real capital, human capital, regression

JEL classification: C01, E22, Q55

\footnotetext{
* Received: 21-08-2015; accepted: 17-06-2016

1 Associate Professor, University of Economics and Innovation, Institute for the Application of Quantitative Methods in Economics, Lublin, 20-209 Lublin, ul. Projektowa 4, Poland. Scientific affiliation: application of quantitative methods in economics. Phone: +048 605630443. E-mail:jan.zwolak@yahoo.com.
} 


\section{Introduction}

The aim of the study is to establish the regression dependency between sold production of new and significantly improved goods and innovation investment in the form of real and human capital flows in the Polish industry in the years 2011-2013. An additional goal is to indicate the impact of real and human capital on the relative increase in innovative sold production in the Polish industry.

The theory of innovation development may serve us to derive the concept of national and regional systems of innovation, which is employed as an analytical framework of empirical data for the elaboration of innovation policy (Doloreux and Parto, 2005). A region requires innovation for profit and to build a competitive position in the global economy, which increases the efficiency of investments on the basis of innovation (Grillo et al., 2011). A company's innovative system is the basis for the implementation of resource factors, including the amount of knowledge required to build a competitive advantage (Rostášová and Chrenková, 2010).

The innovative potential expresses the company's ability to make effective use of resources in order to develop new processes and products (Žižlavský, 2011). The driving force behind growth is innovation that enables the survival and stabilisation of the competitive position of the industry (Galvez et al., 2013). In the earlier years, the innovation of the Polish economy was moderate in nature, while currently it is included among modest innovators (Innovation Union Scoreboard, 2013).

The basis for the research was a hypothesis that impact of physical capital on a relative increase in innovative production in Polish industry over the period 20112013 is greater than impact of human capital.

The article is structured as follows: Section 2 contains a review of economic literature. Section 3 presents a methodology concept. Section 4 sets out the parameters of variables in the area of innovation. Section 5 contains the research findings and discussion. The conclusions are presented in the final section.

\section{Literature review}

The level and dynamics of capital expenditures on research and development (R\&D) efforts are key aspects for the development of knowledge-based industry. Pursuant to Peter Sullivan's (2000) definition, knowledge that can be converted into profit is intellectual capital. Such knowledge conversion makes it an asset of a company. The major drivers of technological changes include research and development efforts undertaken by science, which results in new processes, new knowledge and new products. The relationships between research development and innovations are complex rather than linear; new goods, new services and higher 
quality final products are created, but also new manufacturing processes and procedures (enterprise resources) (Guellec, Pottelsberghe de la Potterie, 2001).

The development of the second material real capital sets the rate and nature of technical progress, which is driven by human capital development (Romer, 1990). The works of Robert M. Solow (1971) on consumption development are also in a similar research stream.

The econometric research on economic growth drivers indicated problems existing between politics, institutions and economic growth in OECD countries. On top of the original impacts of human capital accumulation, the research findings confirm the significance of factors such as: the growth of $R \& D$ efforts undertaken by science, macroeconomic environment, openness to trade, as well as well-developed financial markets. The influence of politics on the efficiency and mobilization of resources during investment in fixed assets was also confirmed (Bassanini, Scarpetta, 2001/II).

OECD countries' data on the economics of the labour force show that empirical work in education using macro-data can be useful. It was proven that labour force productivity is directly proportional to the benefits of educational productivity (Temple, 2001/II).

A new approach has been established to search for endogenic technological effects caused by exogenic business activities. The innovation stimuli are usually stronger for the endogenic rather than for the exogenic effects of business activities. Consequently, the endogenic effects of business activities may reverse the drivers so that the innovation stimuli are stronger in the volume-driven rather than the price-driven competitive environment (Gersbach, Schmutzler 2003).

The research on relationships between productivity, technology and economic growth shows that the total productivity index is not a measure of technological changes, and only in perfect conditions can it be used to measure extraordinary benefits from technological changes (Carlaw, Lipsey, 2003). The economic growth driving forces are not extra benefits caused by technological change, but the continuous process of creating opportunities and options for technological development in the future. The author believes that, relatively, the best measure of the average and marginal productivity of resource drivers is research on productivity based on an empirical model; research on the productivity of a certain driver resource, with the remaining driver resources being at the average level. This allows us to capture the nature of productivity changes during rising levels of a certain driver resource, with the remaining drivers being at the average level. Such productivity changes with the extreme reach of a certain driver resource allows the calculation of the average growth rate of the average and marginal productivity of the driver resource at pace with an increase of its application rate in the industry. 
This methodology was used in this article, and the approach is consistent. However, in order to derive individual income, the source of individual income for each employee has to be determined proportionally to the volume of work performed (Castagnini, Menon and Perali, 2004).

\section{The concept of research methodology}

The issue of the measurement of the correlation of explanatory variables is associated with the correct approach to the quantification of these variables. However, the correlation may vary together with the change in the definition of each variable.

The following empirical variables were adopted:

$\mathrm{Y}$ - the value of sold production of new and significantly improved goods,

$x_{1}$ - expenditures (value) for research and development activities,

$x_{2}$ - expenditures (value) for knowledge from external sources and software,

$x_{3}$ - expenditures (value) for buildings, installations and land,

$x_{4}$ - expenditures (value) for machinery, technical equipment, tools and means of transport,

$x_{5}$ - training and marketing,

$x_{6}-x_{2}+x_{5}$, correlation of $x_{2}$ and $x_{5}$ equal, while $x_{6}$ higher by $10 \%$,

$x_{7}-x_{3}+x_{4}$, correlation of $x_{3}$ and $x_{4} \mathrm{z} \mathrm{Y}-x_{4}$ higher by $10 \%$, while $x_{7}$ with $\mathrm{Y}$ are growing by almost $10 \%$,

$x_{8}-x_{1}+x_{2}+x_{5}$, correlation of $x_{2}$ and $x_{5}-$ equal, and $x_{3}$ with $\mathrm{Y}$ in relation to $x_{2}$ and $x_{5}$ are higher by $10 \%$, while $x_{8}$ with Y are higher by nearly $20 \%$,

$\varepsilon$ - random component.

The establishment of a correlation between the explanatory variables and each of them with the dependent variable (Y) has been executed with the help of the correlation matrix and the correlation coefficients of logarithms, at a significance level of $\mathrm{p}<0.05 ; \mathrm{N}=48$.

Therefore, the following curvilinear Cobb-Douglas exponential function has been proposed:

$$
\mathrm{Y}=a x_{1}^{b} x_{2}^{c} x_{3}^{d} x_{4}^{e} x_{5}^{f} \varepsilon
$$

This dependency can also be written as follows: 


$$
\mathrm{Y}=a x_{1}^{b} x_{3}^{d} x_{4}^{e} x_{6}^{g}
$$

or:

$$
\mathrm{Y}=a x_{1}^{b} x_{2}^{c} x_{5}^{f} x_{7}^{h}
$$

or:

$$
\mathrm{Y}=a x_{7}^{h} x_{8}^{i}
$$

All of these equations are equipotential. In contrast, the correlations between explanatory variables in the above equations are different. It is also worth noting that various explanatory variables are the elements (participations) of the expenditure streams in the structure of real and human capital.

The subject of the estimation of logarithmic empirical data by means of the least squares method is the value of sold production of new and significantly improved goods and its innovation expenditures in the Polish industry in the years 2011-2013. Only in equations (4) in the years 2005-2007 and (2) in the period of 2008-2010 the function parameters lie at a significance level of the range: 0.00-0.05. However, these are determined regression dependencies which are remote in time.

Redefining the explanatory variables is aimed at maintaining their interpretative meaning at their higher correlation with the dependent variable (Y) and at a lower correlation between the explanatory variables themselves. This principle is the basis for obtaining a good regression. A redefinition of the explanatory variables $x_{7}$ and $x_{8}$ (4) results in directing investment flows towards preserving the meaning of the interpretative categories of real and human capital and their regression dependency with production sold of new and significantly improved goods in the Polish industry. The regression dependencies obtained have been shown in Table 2 .

The research was conducted over three-year periods, according to the methodological standards for studies on innovations, which are applied in all OECD countries.

The empirical data have been expressed in 2005 prices, and, therefore, in fixed prices, which allows the comparability of the numerical figures with the calculated function parameters. The fixed prices of 2005 made it possible to increase the number of sets $\mathrm{N}=48$, whereby the studies included all Polish provinces over a period of three years (2011-2013). The year 2005 is a point of time which begins the Polish economic growth within the structure of the EU.

The study of randomness of the distribution of the random component was carried out by means of a graphic analysis and the number series test, at a significance level of 0.05 . The graphic analysis and the number series test confirm the verification of the hypotheses on the accuracy of the chosen analytical form of the model (Table 
2). To study the normality of the random component, the Kolmogorov-Liliefors test was employed. The calculated values compared with the critical values at a significance level of 0.05 do not provide a basis to reject the hypothesis of a normal distribution of the random components. The autocorrelation was checked using the Durbin-Watson test, on which basis a lack of autocorrelation of the random component was established at a significance level of 0.05 . In order to verify the hypothesis of homoscedasticity of the random components, the Goldfeld-Quandt test was implemented (Aczel and Sounderpandian, 2002, p. 587). At an assumed significance level of 0.05 , the observed Snedecor's F distribution critical values are higher than the calculated ones, therefore, there is no basis to reject the hypothesis of homoscedasticity of the random components.

\section{Data and empirical analysis}

Certain characteristics (arithmetic mean, range min. - max. and coefficient of variation) describing the properties of the distribution of the studied attributes have been defined. Empirical data of the entire population have been analysed, and so their characteristics are referred to as parameters. They are presented in Table 1.

The aim of the innovative activity on the part of industrial enterprises is to market new and significantly improved products. The average level of the sold production of these products in the Polish industry over the period 2011-2013 amounts to PLN 7156 million (Table 1). This is a classic measure of the distribution position and the measure of tendency of the central value of the attribute. Changing any of the feature values in the set of empirical data involves a change of the arithmetic mean. It is the result of a broad set of extreme values of the attribute in a ratio of 1 : 46 , whereas the internal variability of the value of the sold production of new and significantly improved goods is moderate.

Expenditure on buildings, installations and land constitute the immobile tangible assets. In this expenditure group, there are also investment flows for the new machinery, technical equipment, tools and means of transport; even though they belong to mobile tangible assets $\left(\mathrm{x}_{7}\right)$, they are responsible for the passive technology transfer to industrial companies. Under the Polish conditions, they also constitute the prime area of innovation activity. Nearly 3 times higher is the combined average level of expenditure on buildings, installations and land together with machinery, technical equipment, tools and means of transport than the expenditures on R\&D activities, knowledge from external sources and software, or for training and marketing. In contrast, the internal variability of expenditures on buildings, installations and land, together with machinery, technical equipment, tools and means of transport is minimised. At the same time, the range of extreme characteristics of the above variable represents a ratio of 1:31. It is narrowed with 
respect to the set of sold production of new and significantly improved goods by one third, while the internal variability is smaller by almost 15 percentage points.

Table 1: Parameters of the attributes in the Polish industry in the period 2011-2013

-2005 prices

\begin{tabular}{|l|c|c|c|c|c|}
\hline \multicolumn{1}{|c|}{ Specification } & Symbol & $\begin{array}{r}\text { Unit of } \\
\text { measure }\end{array}$ & $\begin{array}{c}\text { Arithmetic } \\
\text { mean }\end{array}$ & $\begin{array}{c}\text { Range } \\
\text { min. - max. }\end{array}$ & $\begin{array}{c}\text { Coefficient } \\
\text { of variation } \\
\%\end{array}$ \\
\hline $\begin{array}{l}\text { The value of sold } \\
\text { production of new and } \\
\text { significantly improved } \\
\text { goods }\end{array}$ & $\mathrm{Y}$ & $\begin{array}{c}\text { million } \\
\text { PLN }\end{array}$ & 7156,0 & $629.3-28920.3$ & 112.9 \\
\hline $\begin{array}{l}\text { Expenditures (value) } \\
\text { for machinery, technical } \\
\text { equipment, tools and } \\
\text { means of transport }\end{array}$ & $\mathrm{x}_{7}$ & $\begin{array}{c}\text { million } \\
\text { PLN }\end{array}$ & 977.6 & $127.9-3978.4$ & 98.2 \\
\hline $\begin{array}{l}\text { Expenditures (value) for } \\
\text { research and development } \\
\text { activities and knowledge } \\
\text { from external sources and } \\
\text { software }\end{array}$ & $\mathrm{x}_{8}$ & $\begin{array}{c}\text { million } \\
\text { PLN }\end{array}$ & 341.4 & $20.4-1890.7$ & 120.8 \\
\hline
\end{tabular}

Source: Author's calculations

The value of innovation at a given market price depends on the growth rate and the structure of the streams forming human capital. In the adopted variable $\left(x_{8}\right)$, the flow of human capital is represented by expenditure on research and development, knowledge from external sources and software as well as training and marketing. The range of extreme values of a data attribute in a set represents a ratio of 1: 93 and it is extended by about two-thirds with respect to real capital, which means that the internal variability of human capital is higher by nearly 23 percentage points, as relative to real capital. Deducible there from is an asymmetry in the relationship between the two capitals. It must also be assumed that under given technical conditions, an increase in the value of innovation of the sold production is directly proportional to the increase in the expenditure flow for human capital. This indicates that the main role in the impact on the relative volatility of the value of sold production of new and significantly improved goods in Polish industry is played by human capital. 


\section{Results and discussion}

Rapid changes in technology in enterprises result in the shortening of production cycles, with the simultaneous absorption of knowledge and a more accurate anticipation of future technological developments (Peltoniemi, 2007). Economic conditions, however, define the innovative implementation of the Polish industry. These conditions are contained in the empirical data expressed in prices of 2005 and their regression dependencies have been shown using a curvilinear exponential regression of Cobb-Douglas type, together with statistical assessment thereof; these are included in Table 2.

Table 2: Regression dependence of innovative production (Y) on physical capital $\left(x_{7}\right)$ and human capital $\left(x_{8}\right)$ expenditure

\begin{tabular}{|c|c|c|c|c|c|c|c|c|c|c|c|c|}
\hline \multirow[t]{2}{*}{$a^{*}$} & \multicolumn{2}{|c|}{$\begin{array}{c}\text { Regression } \\
\text { coefficient }\end{array}$} & \multicolumn{3}{|c|}{ Standard error } & \multicolumn{3}{|c|}{ T-Test } & \multicolumn{3}{|c|}{$\begin{array}{c}\text { Level of } \\
\text { significance }\end{array}$} & \multirow[t]{2}{*}{$\mathrm{R}^{2}$} \\
\hline & $x_{7}$ & $x_{8}$ & a & $x_{7}$ & $x_{8}$ & $\mathrm{a}$ & $x_{7}$ & $x_{8}$ & $\mathrm{a}$ & $x_{7}$ & $x_{8}$ & \\
\hline 1.617 & 0.868 & 0.190 & 0.77 & 0.18 & 0.09 & 2.1 & 4.7 & 2.3 & 0.04 & 0.00 & 0.05 & 0.67 \\
\hline
\end{tabular}

Note: $\mathrm{a}^{*}$ - dilogarithm equation constant.

Source: Author's calculations

Regression dependence between the sold production of new and significantly improved goods $(\mathrm{Y})$ and the expenditures on buildings, installations and land together with machinery, technical equipment, tools and means of transport $\left(x_{7}\right)$ and the expenditure on R\&D activities, knowledge from outside sources, software, as well as training and marketing $\left(x_{8}\right)$ in the Polish industry over the years 2011-2013 are included in Table 2. These aggregated variables $\left(x_{7}\right.$ and $\left.x_{8}\right)$ have explained the variability of sold production of new and significantly improved goods in $67 \%$. This is a satisfactory explanation. The value of $\mathrm{R}^{2}$ above 0.9 - a very good explanation, above 0.8 - a good one, and above 0.6 - satisfactory (Aczel, Sounderpandian, 2002). The remaining unexplained volatility of the value of innovative production sold is realised by variables which have not been included in the study. The strength of the relationship, which has been expressed by the correlation coefficient (R) between the value of sold production of new and significantly improved goods and the expenditure on buildings, installations and land, together with machinery, technical equipment, tools and means of transport and the expenditure on R\&D activities, knowledge from external sources and software and training and marketing, amounts to $82 \%\left(\sqrt{R^{2}}\right)$.

It is a strong correlation between all the variables. Bajgar et al. in 2012 distinguish in the range of $0.10-0.39$ a poor correlation, $0.40-0.69$ an average correlation, 0.70-0.89 a strong correlation and a very strong correlation in the range $0.90-1.00$. 
Standard errors of the regression coefficients (parameters) are lower than $50 \%$ of their absolute values. T-test values, however, are several times higher than the value of regression coefficients, while the level of significance of regression coefficients ranges between: $0.00-0.05$. These statistical evaluations of regression coefficients (parameters) indicate the possibility of their use in econometric analysis of the volatility of the value of production sold of new and significantly improved goods in the Polish industry in the years 2011-2013.

The regression coefficients and function parameters at $x_{7}$ and $x_{8}$ define the flexibility (flexibility coefficients) of the value of sold production of new and significantly improved goods, as relative to expenditures on buildings, installations and land, together with machinery, technical equipment, tools and means of transport, as well as the expenditure on R\&D activities, knowledge from external sources, software, training and marketing in the Polish industry in the years 2011-2013. The perception of the role of resource factors is made possible by the use of Cobb Douglas production function (Zimkova and Barochowsky, 2007).

Thus, the regression coefficients (function parameters) serve as flexibility coefficients. They are the flexibilities of $\mathrm{Y}$ with respect to $x_{7}$ and $x_{8}$, and according to Clark's marginal productivity theory of distribution, they are participations in innovation expenditure of these factors $\left(x_{7}\right.$ and $\left.x_{8}\right)$ in the product (in the innovative production sold) (Solow, 1956, p. 556). In the exponential regression, the exponents with explanatory variables are interpreted as coefficients of variable flexibility which is endogenous with respect to the relevant factors. A flexibility coefficient determines by how many percentile points, on average, the dependent variable changes (increases or decreases) when the $x_{j}$ factor increases by $1 \%$, assuming the constancy of the remaining factors. It is a regressive relationship rather than a causal one, the latter being difficult to prove.

The flexibility of sold production of new and significantly improved goods (Table 2 ) is higher with respect to the expenditures on buildings, installations and land together with machinery, technical equipment, tools and means of transport (0.868) than the spending on R\&D activities, knowledge from external sources, software, training and marketing (0.190). The first group of expenditures represent real capital flows, while the latter are streams of human capital. The relationship of regression coefficients (flexibility coefficients) indicates that sold production of new or significantly improved goods with respect to expenditures on buildings, installations and land together with machinery, technical equipment, tools and means of transport is more than 4.5 times greater than the combined spending on R\&D activities, knowledge from external sources, software, training, and marketing. It should be noted that decisions concerning the implementation of real capital are shaped by the environment of a given entity and, as such, they are independent of the decisions taken by individual business entities. Therefore, an increase in expenditure on human capital remains a major explanatory variable in 
the regression model of the innovation growth rate (theory). Since human capital is characterised by certain specificity and its own complex mechanism, the flexibility of sold production of new and significantly improved goods in terms of human capital forms only a part of the overall effect of the product. Thus, the structure of the regression model of innovation growth rate (Cobb-Douglas) assumes that the flexibility of the produced innovation values in relation to the human capital equals unity. The above-stated logical interpretations of the regression model of the innovation growth rate (theory) indicate that at a certain studied technical level of the Polish industry, the impact of human capital investment streams is used in $19 \%$ relative to the potential impact of human capital. Human capital is the strength of the Polish economy, but it is not fully utilised. This is due to a very small number of innovative enterprises in the Polish economy.

We are therefore dealing with an imbalance in the influence of innovation expenditures that has no place in innovative economies where all dimensions of the innovation potential are crucial for its effective use. Research confirms that higher education is a legitimate strength of innovation in transition economies. However, this effect is significantly lower for companies from Eastern European countries. Studies also suggest that the access to the European Union has not affected this issue by much (Nazarov et al., 2012).

The model of innovation growth rate (Cobb-Douglas) indicates that the flexibility of innovation value with respect to real capital should be less than unity. In this study, it is less than unity $(0.868)$, but it constitutes $80 \%$ of the flexibility of sold production of new and significantly improved goods relative to real capital expenditure streams at a relatively constant level of other factors. The greatest influence on the shaping of volatility of sold production of new and significantly improved goods is yielded by expenditure on buildings, installations and land, especially the investment in new machinery, technical equipment, tools and means of transport, which are responsible for the passive transfer of technology to enterprises. They constitute the main area of innovative activity in industry and a typical phenomenon in the Polish economy.

The sum of the flexibility coefficients (exponentiation) (Table 2) greater than unity (1.058) indicates that the sold production of new and significantly improved goods relative to the combined effects of expenditures on buildings, installations, land and machinery, technical equipment, tools and means of transport, together with the expenditure on research and development activities, knowledge from outside sources and software, as well as training and marketing, has grown more than proportionally, with a relatively stable level of other expenses. Therefore, increasing economies of scale were observed for sales of new and significantly improved goods in the Polish industry. The total $10 \%$ increase in the expenditure on buildings, installations and land together with machinery, technical equipment, tools and means of transport, as well as the expenditure on R\&D activities, 
knowledge from external sources, software, training and marketing results in an increase in sold production of new and significantly improved goods by about $10.58 \%$. Sold production of new and significantly improved goods has a relatively constant marginal utility and its markets are not subject to restrictions related to saturation levels. Therefore, at affordable prices and with an increase in demand (economies of scale and reduced usual costs) a market for such products is a market which dynamises the whole economic system. Moreover, the above-specified goods may contribute to the development of new markets.

The impact proportion (the sums of flexibility $=100 \%$ ) (Table 2 ) shows that the impact of expenditures on buildings, installations and land together with machinery, technical equipment, tools and means of transport on the relative increase of sold production of new and significantly improved goods amounts to $82 \%$, and with respect to spending on research and development activities, knowledge from external sources, software, training and marketing, it is as high as $18 \%$.

With more than a proportional increase of the sum of expenditures on real and human capital to the relative increase in sold production of new and significantly improved goods, the relatively low value of human capital at a low value of innovation potential causes a significant reduction in the growth of that production in the Polish industry over the years 2011-2013. This is indicated by the imbalance between the impact of human capital in relation to real capital that prevents a relative increase of sold production of new and significantly improved goods at a full utilisation of the innovation potential of the Polish industry.

\section{Conclusions}

The obtained results of the research confirmed the earlier defined hypothesis that the impact of physical capital on a relative increase in innovative production in Polish industry over the period 2011-2013 is greater than impact of human capital. These results are the contribution to the economic literature by building an empirical Cobb-Douglas based model. Namely, the model brings a new contribution to the development of the innovation theory. The model itself $=$ theory. The Cobb-Douglas model is based on empirical data from all provinces (regions) of Poland. Hence, it presents macroeconomic regression dependences and covers the entire industry in Poland. The empirical research was limited by the availability of data at the micro level, i.e. at the level of enterprises, because the empirical data had been aggregated in the statistics of the Central Statistical Office for Poland at the level of provinces (regions). Future research may be limited to a specific province (region) or an industry sector which can help designate a model and use it for innovative industrial policy in a specific province. That will lead to balanced innovativeness in the regions (provinces). In the years 2014-2020, the new EU funds will mainly be used 
for innovations in the provinces. They will be spent on those activities where the innovation effectiveness may go up. The research will contribute to development of human capital and social in result of changes in the education system and adaptation of the system to the needs of innovation implementation in the economy, taking account of its specific economic conditions. The estimated Cobb-Douglas model shows the suggested directions of changes to use innovativeness in the economic system of industry at the level of the entire country. It also shows the fundamentals of the innovation development policy in order to achieve a balanced use of material capital and human capital, and their future economic structure in Polish industry. Finally, the obtained results also should be the basis for the development of an innovative industrial policy in Poland in respect of the funds earmarked for that purpose under the financial forecast for 2014 to 2020.

\section{References}

Aczel, A. D., Sounderpandian, J. (2002) Complete Business Statistics, Illinois, USA: Mc Graw-Hill/Irwin.

Bajgar, R. et al. (2012) “Chi-kvadrát test, korelačni a regresni analýzy. Lékařská biofyzika, biometrie a výpočetni technika. Návody k praktickým cvičenim”. In Univerzita Palackého: Olomouc. Available at: http:/ulb.upol.cz/praktikum/ statistika 3.pdf [Accessed: May 20, 2016].

Bassanini, A., Scarpetta, S. (2001) "The driving forces of economic growth: panel data evidence for the OECD countries", OECD Economic Studies, II, No. 33, 2001/II, pp. 9-56. Available at: https://www.oecd.org/eco/growth/18450995.pdf [Accessed: May 26, 2016].

Carlaw, K. I., Lipsey R. G. (2003) "Productivity, Technology and Economic Growth: What is the Relationship? Megeformatinet", Journal of Economic Surveys, Vol. 17. No. 3, pp. 457-495, doi: 10.1111/1467-6419.00201.

Castagnini, R., Menon, M. and Perali, F. (2004) "Extended and Full Incomes at the Household and Individual Level. An Application to Farm Households", American Journal of Agricultural Economics, Vol. 86, No. 3, pp. 730-736, doi: 10.1111/j.0002-9092.2004.00615.x.

Doloreux, D., Parto, S. (2005) "Regional innovation systems: Current discourse and unresolved issues", Technology in Society, Vol. 27, No. 2, pp. 133-153, doi: 10.1016/j.techsoc.2005.01.002.

Galvez, D., Camargo, M., Rodriguez, J., Morel, L. (2013) "PII - Potential Innovation Index: a tool to benchmark innovation capabilities to international context", Journal of Technology Management \& Innovation, Vol. 8. No. 4, pp. 36-45. Available at: http://dx.doi.org/10.4067/S0718-27242013000500004 [Accessed: May 26, 2016]. 
Gersbach, H., Schmutzler, A. (2003) "Endogenons technological spillovers: causes and consequences", Journal of Economics \& Management Strategy, Vol. 12, No. 2, pp. 179-205, doi: 10.1111/j.1430-9134.2003.00179.x.

Grillo, F., Landabaso, M. (2011) "Merits, problems and paradoxes of regional innovation policies", Local economy, Vol. 26, No. 6-7, pp. 544-561, doi: 10.1177/ 0269094211417161.

Guellec, D., van Pottelsberghe de la Potterie, B. (2001/II) "R\&D and productivity growth: panel data analysis of 16 OECD countries", OECD Economic Studies, No. 33, pp. 103-126, https://www.oecd.org/eco/growth/1958639.pdf [Accessed: June 10, 2016].

Innovation Union Scoreboard (2013) European Commission, Belgium, 5. Available at: https://ec.europa.eu/.../european-commission-innovation-union-sc [Accessed: May 26, 2016].

Nazarov, Z., Akhmedjonov A. (2012) "Education, On-the-job Training and Innovation in Transition Economies", Eastern European Economics, Vol. 50, No. 6, pp. 28 56, doi: 10.2753/eee0012-8775500602.

Peltoniemi, M. (2007) "Why do Managers from Different Firms Exchange Information? A Case Study from a Knowledge intensive Industry", The Electronic Journal of Knowledge Management, Vol. 5, No. 1, pp. 81-88. Available at: www. ejkm.com [Accessed: May 25, 2016].

Romer, P. M. (1990) "Endogenous Technological Change", Journal of Political Economy, Vol. 98, No. 5, pp. S71-S102, doi: 10.1086/261725.

Rostášová, M., Chrenková, A. (2010) "Innovative potential of postal operators in logistics", Logistyka, No. 2, p. 316, Available at: http://www.czasopismologistyka. pl/artykuly-naukowe/send/188-logistyka/834-artykul [Accessed: May 26, 2016].

Solow, R. (1956) “A Contribution to the Theory of Economic Growth", Quarterly Journal of Economics, Vol. 70, No. 1, pp. 65-94. Available at: http://piketty.pse. ens.fr/files/Solow1956.pdf [Accessed: May 25, 2016].

Solow, R.M. (1971) Growth Theory: an Exposition, Oxford: Clarendon Press.

Sullivan, P. (2000) Value - Driven Intellectual Capital, John Wiley and Sons.

Temple, J. (2001/II) "Growth effects of education and social capital in the OECD countries" OECD Economic Studies, No. 33, pp. 57-101. Available at: https:// www.oecd.org/eco/growth/18452154.pdf [Accessed: May 25, 2016].

Zimkova, E., Barochovsky, J. (2007) "Estimation of potential product and output Gap end Slovak Conditions", Politicka ekonomie, Vol. 55, No. 4, pp. 473-489, doi: $10.18267 /$ j.polek.609.

Zizlavsky, O. (2011) "Factors of an innovation potential development are known, but not always mastered",Economics and Management, Vol. 2011, No. 16, pp. 1019-1015. Available at: https://www.vutbr.cz/veda-a-vyzkum/vysledky-vav/ detail?vav_id=36933\#vysledek-36933 [Accessed: May 25, 2016]. 


\title{
Inovativni poduzetnici u poljskoj industriji
}

\author{
Jan Zwolak ${ }^{1}$
}

\begin{abstract}
Sažetak
Svrha ovog istraživanja je utvrditi postoji li povezanost između prodaje novih $i$ značajno poboljšanih proizvoda i fizičkog kapitala i ljudskih resursa u poljskoj industriji u periodu između 2011. i 2013. U kvantitativnoj analizi koristi se Cobb-Douglasov regresijski model, a zajedno s dobivenim parametrima, rezultati pokazuju da postoji viši stupanj fleksibilnosti prodane proizvodnje nove i značajno poboljšane robe prema tokovima izdataka stvarnog kapitala $(0,868)$ u usporedbi s ulaganjima u tokove ljudskih resursa $(0,190)$. Model stope inovacijskog rasta (Cobb-Douglas teorija) pokazuje da fleksibilnost prodane proizvodnje nove $i$ značajno poboljšane robe može biti jednaka jedan. Istraživanjem je utvrđena regresijska ovisnost prodane proizvodnje novih i značajno poboljšanih proizvoda na izdatke za fizički kapital i ljudske resurse. Stoga, neravnoteža u ovim vrstama kapitala utječe na nestalnost prodane proizvodnje nove i značajno poboljšane robe u industriji. Ovakva proizvodnja, koja je ovisna o zajedničkom učinku ulaganja u stvarni kapital $i$ ljudske resurse, u razdoblju od 2011. do 2013. rasla je više od proporcionalnog $(1,058)$. Sadašnji potencijal za inovacije s nepromijenjenom metodom proizvodnje omogućuje povećanje ekonomije razmjera prodane proizvodnje novih i znatno poboljšanih proizvoda u poljskoj industriji. Provedeno istraživanje pokazuje da utjecaj ljudskih resursa $(0,190)$ iznosi samo jednu petinu u odnosu na potencijalne mogućnosti koje pruža Poljska industrija.
\end{abstract}

Ključne riječi: inovacije, stvarni kapital, ljudski resursi i regresija

JEL klasifikacija: C01, E22, Q55

${ }^{1}$ Izvanredni profesor, University of Economics and Innovation, Institute for the Application of Quantitative Methods in Economics, Lublin, 20-209 Lublin, ul. Projektowa 4, Poljska. Znanstveni interes: primjena kvantitativnih metoda u ekonomiji. Tel.: +048605630 443. E-mail:jan.zwolak@yahoo.com. 